Historia Slavorum Occidentis

2021, nr 2 (29)

ISSN 2084-1213

DOI: $10.15804 /$ hso210202

Elżbieta Elena Wróbel (Kraków)

ORCID: 0000-0003-1615-3637

\title{
Alternatywa czy wariant funkcjonującego wzorca? „Kobiecy świat” w Autobiografii mistycznej matki Teresy od Jezusa Marchockiej
}

Keywords: history, Mariana Marchocka, woman, autobiography, mentality

\begin{abstract}
The article analyses the Mystical Autobiography by Marianna Marchocka, showing the significance of her work for the research into the history of the female mentality in the Old Polish era. The main issue was to relate monastic life to the basic ideal of a woman as a wife and mother.
\end{abstract}

Utwory literackie pozwalające lepiej poznać i zrozumieć mentalność naszych staropolskich przodków w zdecydowanej większości były autorstwa męskiej części ówczesnego społeczeństwa. Kobieta pisarka czy poetka, to zjawisko w Rzeczypospolitej XVI i XVII w. prawie niespotykane. Spowodowane to było z jednej strony niskim stopniem alfabetyzacji wśród pań tej epoki, tylko w niewielkim procencie posiadających umiejętność pisania ${ }^{1}$, z drugiej zaś różnym modelem edukacji i wychowania stosowanym wobec chłopców i dziewcząt. Owa odmienność w podejściu do tych

1 Według obliczeń W. Urbana, w Małopolsce w drugiej połowie XVI w. umiejętność pisania posiadało 49\% zamożnych szlachcianek, ok. 20\% kobiet należących do średniej szlachty, ok. 15\% drobnych szlachcianek i ok. 25\% mieszczek, co stanowi (w przybliżeniu) ok. 4\% całej populacji kobiet zamieszkujących w tym czasie na tym terenie. Zob. W. Urban, Umiejętność pisania $w$ Małopolsce $w$ drugiej połowie XVI wieku, Przegląd Historyczny 68 (1977), z. 2, s. 231-257. 
kwestii była mocno związana nie tylko z płcią człowieka, lecz także z określeniem jego miejsca w ściśle zhierarchizowanej strukturze społeczeństwa oraz życiowych funkcji, jakie w przyszłości miał on podejmować. W tym układzie kobiecie przypisywano całkowicie inną rolę niż mężczyźnie, gdyż otoczenie stawiało przed nią jasno określone zadania żony i matki, do czego od dzieciństwa była przygotowywana.

Czy w tym powszechnie przyjętym wzorcu było zatem miejsce na nieco odmienne scenariusze? Wydaje się, że tak, chociaż ze względu na stosunkowo niewielki procent tychże przypadków nie stanowily one reguły, a były raczej od niej wyjątkiem. W takiej sytuacji znajdowała się kobieta zakonnica, a także wdowa, a nawet w pewnym sensie także bezdzietna mężatka. Realizując różny od tradycyjnie przyjętego model przeżywania własnej kobiecości, znajdowały się one niejako na marginesie ówcześnie przyjętego ideału. Ciekawą kwestią wydaje się odpowiedź na pytanie, czy odczuwały to jako brak, czy raczej jako możliwość własnego rozwoju bez ograniczeń, którym podlegała żona i matka. Trudno jednoznacznie to ocenić przede wszystkim dlatego, że posiadamy niewiele źródeł literackich z tamtej epoki, których autorkami były kobiety. Oczywiście, zachowała się pewna spuścizna epistolograficzna z kręgów dworskich, magnackich czy nawet szlacheckich, która wyszła spod pióra ówczesnych pań ${ }^{2}$ jednakże lepiej znana i zachowana jest ta z czasów saskich, znacznie obfitszych w ten rodzaj źródeł ${ }^{3}$. Do naszych czasów przetrwała również część kobiecych testamentów, może nie zawsze sporządzonych ręką samej testatorki, to jednak w pewien sposób przybliżających jej mentalność i sprawy dla niej ważne ${ }^{4}$. Ciekawym

2 Polskie listy mitosne od XV do XIX wieku, oprac. B. Merwin, Lwów-Poznań 1922; R. Ganszyniec, Polskie listy mitosne, Kraków 1925; Maria Kazimiera d’Arquien de la Grange, Listy do Jana Sobieskiego, oprac. L. Kukulski, Warszawa 1966; Listy staropolskie epoki Wazów, oprac. H. Majewska, Warszawa 1977; M. Komaszyński, Epistolografia Marysieńki Sobieskiej, [w:] Wśród zagadnień polskiej literatury barokowej, cz. 1: Światopogląd, genologia, topika, red. Z.J. Nowak, Katowice 1980, s. 60-72; A. Sajkowski, Staropolska miłość. $Z$ dawnych listów i pamiętników, Poznań 1981; A. Nowicka-Struska, Listy w kręgu kulturowym karmelitanek bosych $w$ XVII $i$ XVIII wieku. Ze studiów nad rękopisami $z$ Biblioteki Karmelitanek Bosych, [w:] Epistolografia w dawnej Rzeczypospolitej, t. 5: Stulecia XVI-XIX. Nowa perspektywa historycznoliteracka, red. M. Olma, P. Borek, Kraków 2015, s. 193-214.

3 P. Bohdziewicz, Korespondencja artystyczna Elżbiety Sieniawskiej $w$ zbiorach Biblioteki Czartoryskich z lat 1700-1729, Lublin 1964; B. Popiołek, Na marginesie ważnych spraw. Listy kobiet epoki saskiej, [w:] Rola i miejsce kobiet w edukacji i kulturze polskiej, t. 1, red. W. Jamrożek, D. Żołądź-Strzelczyk, Poznań 1998, s. 89-101; J. Rafałowiczówna, A z Warszawy nowiny te... Listy do Elżbiety Sieniawskiej z lat 1710-1720, oprac. i wstęp B. Popiołek, Kraków 2000.

$4 \mathrm{Z}$ dość obszernej liczby publikacji warto wymienić przynajmniej niektóre: M. Borkowska, De- 
przejawem kobiecego pisarstwa są także kroniki rodzinne ${ }^{5}$. Ważnym środowiskiem rozwoju intelektualnego pań był również dwór królewski, gdzie z inspiracji pochodzących z Francji kolejnych królowych zaczął kształtować się model kobiety uczonej, interesującej się poezją, sztuką, teatrem, a także astronomią ${ }^{6}$ I chociaż w tym kręgu raczej nie powstały $\mathrm{w}$ tym czasie rodzime utwory, to jednak cała atmosfera intelektualnego rozwoju panująca wśród dworek była inspirująca dla kobiet mających z nimi kontakt, wpływając także na rozwój ich zainteresowań. Dopiero epoka saska wydała polskie literatki, które na trwałe wpisały się w naszą kulturę ${ }^{7}$ Jednakże było to nadal zjawisko raczej marginalne, nie posiadające szerszego przełożenia na większą liczbę pań posługujących się piórem. Dlatego też staropolski „świat kobiecy" nadal pozostaje mało rozpoznany, często ograniczony do zewnętrznego oglądu tejże rzeczywistości, dokonywanego i przekazywanego potomnym przez mężczyzn.

Na szczególną uwagę badaczy tej problematyki zasługują ówczesne klasztory żeńskie, które były literacko najbardziej aktywnym, a zarazem jednorodnie kobiecym środowiskiem. To zagadnienie było już niejednokrotnie prezentowane i omawiane w literaturze ${ }^{8}$. Wśród zakonnic, które pozostawiły po sobie „pisarski” ślad, w sposób

kret $w$ niebieskim ferowany parlamencie. Wybór testamentów $z$ XVII-XVIII wieku, Kraków 1984; A. Karpiński, Zapisy pobożne i postawy religijne mieszczek polskich w świetle testamentów $z$ drugiej polowy XVI i XVII wieku, [w:] Tryumfy i porażki. Studia z dziejów kultury polskiej XVI-XVIII wieku, red. M. Bogucka, Warszawa 1989; U. Augustyniak, Testamenty ewangelików reformowanych $w$ Wielkim Księstwie Litewskim, Warszawa 1992; M. Aleksandrowicz-Szmulikowska, Radziwittówny w świetle swoich testamentów. Przyczynek do badań mentalności magnackiej XVI-XVIII wieku, Warszawa 1995; M. Górny, Testament Cecylii z Działyńskich Baranowskiej z 1736 roku, Genealogia. Studia i Materiały Historyczne 7 (1996), s. 105-114; A. FalniowskaGradowska, Testamenty szlachty krakowskiej XVII-XVIII w. Wybór tekstów źródłowych z lat 1650-1799, Kraków 1997; B. Popiołek, Woli mojej ostatniej testament ten... Testamenty staropolskie jako źródło do historii mentalności XVII i XVIII wieku, Kraków 2009.

5 K. Targosz, Sawantki w Polsce XVII w. Aspiracje intelektualne kobiet ze środowisk dworskich, Warszawa 1997, s. 275-279.

6 Taż, Uczony dwór Ludwiki Marii Gonzagi (1646-1667). Z dziejów polsko-francuskich stosunków naukowych, Wrocław 1975; taż, Sawantki w Polsce XVII w.

7 B. Popiołek, Kobiecy świat w czasach Augusta II. Studia nad mentalnościa kobiet z kręgów szlacheckich, Kraków 2003.

8 Wśród prac poświęconych tej tematyce należy wymienić m.in.: K. Górski, A.M. Borkowska, Historiografia zakonna a wzorce świętości XVII w., Warszawa 1984; H. Popławska, Kultura literacka karmelitanek bosych (XVII-XVIII wiek), Gdańsk 2006; taż, Żywoty i autobiografie w rękopiśmiennych zbiorach Biblioteki Karmelitanek Bosych na Wesotej w Krakowie, [w:] Staropolska kultura rękopisu, red. H. Dziechcińska, Warszawa 1990, s. 191-209; M. Borkowska, Życie codzienne polskich klasztorów żeńskich w XVII-XVIII wieku, Warszawa 1996, s. 287-328; K. Targosz, 
szczególny wyróżnia się Marianna (Anna Maria) Marchocka (1603-1652), bardziej znana jako matka Teresa od Jezusa, karmelitanka bosa ${ }^{9}$. Jest ona jedną z pierwszych autorek, które odważyły się opisać swoje życie ${ }^{10}$, pozostawiając po sobie dzieło, któremu potomni nadali tytuł Autobiografia mistyczna ${ }^{11}$. Po raz pierwszy szerszemu gronu czytelników utwór ten udostępnił Karol Górski, opracowując go krytycznie i wydając drukiem w $1939 \mathrm{r}^{12}$, ponowne zaś wydanie tegoż dzieła ukazało się w $2010 \mathrm{r}$. w przygotowaniu o. Czesława Gila ${ }^{13}$. Sama postać matki Teresy Marchockiej doczekała się biografii pióra swojego spowiednika, który przy jego redakcji posłużył się przede wszystkim wiadomościami zaczerpniętymi wprost z jej Autobiografi ${ }^{14}$, o. Rafał Kalinowski zaś opublikował ją ponownie na początku XX w. ${ }^{15}$ Najnowsze ustalenia dotyczące życiorysu matki Marchockiej, pozwalające na weryfikację informacji zawartych w samej Autobiografii, ale także w Żywotach, przytoczył w swoich

Sawantki $w$ Polsce XVII w.; taż, Piórem zakonnicy. Kronikarki w Polsce XVII w. o swoich zakonach i swoich czasach, Kraków 2002; A. Nowicka-Struska, Rękopisy karmelitanek bosych w XVII i XVIII wieku - ekspresja artystyczna i sztuka pisania, [w:] Marginalia w książce dawnej i wspótczesnej, red. B. Mazurkowa, Katowice 2019; taż, Za murami klasztoru. Historiografia lubelskich karmelitanek bosych, Acta Universitatis Lodziensis. Folia Litteraria Polonica 53 (2019) 2, s. 79-116.

9 Zob. K. Górski, Marchocka Anna Maria, [w:] Polski Stownik Biograficzny, t. 19, z. 4, red. E. Rostworowski, Wroclaw 1974, s. 549-550.

10 Przed nimi można znaleźć kilka przykładów pań, które zostawiły po sobie spuściznę literacką, jednak Marianna Marchocka oraz nieco od niej młodsza Anna ze Stanisławskich Zbąska są pierwszymi polskimi autorkami kobiecych autobiografii. Por. K. Targosz, Sawantki w Polsce XVII w., s. 307-313.

11 Matka Teresa od Jezusa zaczęła ją spisywać w 1647 r. na polecenie swojego spowiednika o. Ignacego od św. Jana Ewangelisty (zm. 1677), czyniąc to prawie do swojej śmierci zobowiązana posłuszeństwem. Zob. Teresa od Jezusa (Marianna Marchocka), Autobiografia mistyczna i inne pisma, opr. C. Gil, Kraków 2010, s. 14-16.

12 Autobiografia mistyczna m. Teresy od Jezusa karmelitanki Bosej (Anny Marii Marchockiej) 1603-1652, wyd. K. Górski, Poznań 1939.

13 Teresa od Jezusa (Marianna Marchocka), Autobiografia mistyczna.

14 Ignacy od św. Jana Ewangelisty, Żywot i wysokie cnoty W. Matki Teresy od Pana Jezusa Marchockiej, klasztorów karmelitanek bosych we Lwowie i Warszawie fundatorki z manuskryptu dziejopisa W. Ojca Ignacego od świętego Jana Ewangelisty tej Wielebnej Matki spowiednika zebrane Roku Pańskiego 1654, Lwów 1752.

15 Pod tytułem Żywot Wielebnej Matki Teresy od Pana Jezusa Marchockiej, klasztorów karmelitanek bosych we Lwowie $i$ Warszawie fundatorki, z rękopisu o. Ignacego od św. Jana Ew. k.b. tej Wielebnej Matki spowiednika ułożony i z innych źródeł uzupetniony, Kraków 1901. 
opracowaniach wspominany już o. Gil ${ }^{16}$. Dzieło to doczekało się również kilkunastu analiz, które starały się ukazać zarówno jego wartość od strony teologicznej ${ }^{17}$, jak i jego znaczenie dla dziejów naszej literatury ${ }^{18}$. Dotychczas jednak utwór ten, tak wyjątkowy pod wieloma względami, nie był wykorzystywany do badań nad staropolską mentalnością. Zasługuje zaś na baczniejszą uwagę w tym względzie, gdyż jak już wcześniej podkreślono, jest pierwszą rodzimą kobiecą próbą opisania własnych przeżyć wewnętrznych, co stanowi niezwykle rzadką tematykę ówczesnej twórczości. I chociaż doświadczenia natury duchowej czy religijnej są przedmiotem badań przede wszystkim teologa, to jednak w treści utworu znajduje się tak wiele wątków obyczajowych, że stanowią one interesujący materiał również dla historyka. Ciekawe są przede wszystkim epizody ukazujące konkretną kobietę w kontekście otaczającej ją rzeczywistości i wyzwań, z którymi musiała mierzyć się podczas swojego życia, co czyni z jej rozważań szczególnie ważne świadectwo o ludziach tamtej epoki.

16 C. Gil, Matka Teresa od Jezusa (Marianna Marchocka) karmelitanka bosa 1603-1652, Karmelitańskie Studia i Materiały Historyczne 1 (2006), s. 13-111; tenże, Wstęp, [w:] Teresa od Jezusa (Marianna Marchocka), Autobiografia mistyczna, s. 5-31.

17 K. Górski, Anna Maria Marchocka m. Teresa od Jezusa (1603-1652) karmelitanka bosa, Nasza Przeszłość 41 (1974); s. 21-28; tenże, Od religijności do mistyki. Zarys dziejów życia wewnętrznego $w$ Polsce, cz. 1, 966-1795, Lublin 1962, s. 99-120; tenże, Zarys dziejów duchowości $w$ Polsce, Kraków 1986, s. 140-156; J.K. Goliński, Mistyka i łaska. Życie wewnętrzne Marianny Marchockiej w świetle „Żywota”, [w: ] Pisarki polskie epok dawnych, red. K. Stasiewicz, Olsztyn 1998, s. 57-67; J.W. Gogola, Życie mistyczne Teresy od Jezusa Marchockiej karmelitanki bosej 1603-1652. Studium z duchowości karmelitańskiej, Kraków 1995; tenże, Teresa od Jezusa - Marchocka, karmelitanka bosa 1603-1652: życie i doświadczenie mistyczne, Karmel 1 (2002), s. 65-76; A. Jocz, Anna Maria Marchocka - polska reprezentantka karmelitańskiej szkoły duchowości, [w:] Duchowość i religijność kobiet dawniej i dziś, red. E. Pakszys, L. Sikorska, Poznań 2000, s. 113-125; K. Kaczor-Scheitler, Droga do doskonałości Anny Marii Marchockiej w świetle jej „Autobiografii”, [w:] O doskonałości. Materiaty z konferencji 21-23 maja 2001, red. A. Maliszewska, cz. 2, Łódź 2002, s. 145-159; taż, Mistycyzm hiszpański w piśmiennictwie polskich karmelitanek XVII i XVIII wieku, Łódź 2005, s. 92-129; W. Grupiński, „Autobiografia mistyczna” Marianny Marchockiej jako kłopot $i$ dar dla teologa, Poznańskie Studia Teologiczne 24 (2010), s. 191-213; L. Sokół, Problem cierpienia w „Autobiografii mistycznej" Anny Marii Marchockiej, Meluzyna 5 (2016) 2, s. 35-48.

18 H. Popławska, Żywoty i autobiografie, s. 191-209; taż, Autobiografia mistyczna, [w: ] Religijność literatury polskiego baroku, red. C. Hernas, M. Hanusiewicz, Lublin 1995, s. 101-123; C. Hernas, Barok, Warszawa 1998, s. 378-381; K. Targosz, Damy XVII wieku z piórem w ręku, [w:] Pisarki polskie epok dawnych, red. K. Stasiewicz, Olsztyn 1998, s. 11-33; taż, Piórem zakonnicy; W. Grupiński, Wewnątrz. Rzecz o Autobiografii mistycznej Marianny Marchockiej, Warszawa 2005. 
Zresztą Marianna Marchocka pisarką stała się niejako wbrew sobie, gdyż jak wspominała, podjęła się tego zadania jedynie z posłuszeństwa wobec spowiednika, który nakazał jej taką pracę i przyznawała, że „[nad] ten akt nie było mi nic cięższego w posłuszeństwie"19. Jednakże już na początku swojej wypowiedzi przypominała otrzymaną od niego obietnicę, że „o tym nie będzie nikt wiedział ani tego widział, tylko W[asza] M[iłość sam, i zaraz W[asza] M[iłość] spali, o co ja i teraz pokornie proszę [...]”20. Ponieważ ów kapłan tylko połowicznie dotrzymał swojej obietnicy, niszcząc oryginał zapisków Marchockiej a zachowując odpis, możemy dzisiaj zapoznać się z pierwszą w dziejach rodzimej literatury zachowaną próbą kobiecej autobiografii. Nie jest to jednak typowe opisanie własnego życia. Główny nacisk bowiem autorka położyła na swoje przeżycia wewnętrzne, duchowe, gdyż taki był zamysł podjętych przez nią wysiłków pisarskich. Dlatego też dzieje życia, które w typowej autobiografii byłyby pierwszoplanowe, tutaj stają się jedynie tłem potrzebnym do ukazania tego, co dla Matki Teresy od Jezusa było najistotniejsze, czyli jej drogi ku Bogu i wewnętrznych zmagań temu towarzyszących. Jednakże nawet te nieliczne wzmianki ukazujące chociażby tę część życia, którą rozpoczynając życie w klasztorze, pozostawiła niejako za sobą, pozwalają na bliższe przyjrzenie się również tym okolicznościom, które kształtowały jej życie i osobowość jeszcze przed wstąpieniem do Karmelu.

\section{Rodzina - relacje wpisane w model zasadniczy}

Zasadniczym środowiskiem funkcjonowania „kobiecego świata”, wpisującym się w staropolski sposób jego postrzegania, była rodzina. Dla urodzonej w 1603 r. Marianny był to przede wszystkim jej dom rodzinny, stworzony przez ojca Pawła Marchockiego (1564-1631) ${ }^{21}$ starostę czchowskiego i Elżbietę z Modrzejewskich. Jego obraz, wyłaniający się z pierwszych rozdziałów autobiografii, wydaje się typowy dla środowiska szlacheckiego, w którym dziewczęta wychowywały się pod bacznym okiem matki, dorastając do wypełnienia najważniejszych ról w swoim przyszłym życiu, czyli żony i matki. Z opisu obojga rodziców widać, że bliższe więzi emocjonalne łączyły autorkę raczej z ojcem niż z matką, co może nie było regułą w staro-

\footnotetext{
19 Teresa od Jezusa (Marianna Marchocka), Autobiografia mistyczna, s. 37. Tamże.

21 Zob. J. Michalewicz, Marchocki Pawet, [w:] Polski Słownik Biograficzny, s. 554-555.
} 
polskim domu, ale na tyle częstym zjawiskiem, że zasługującym na odnotowanie ${ }^{22}$. Marchocka, pomimo podkreślania roli matki w kształtowaniu swojej osobowości czy religijności, zauważała pewną nierówność w traktowaniu przez nią obu swoich córek. Odczuwała, że matka bardziej kocha starszą Elżbietę, a kiedy Mariannie „ociec i wszyscy większą miłość pokazowali, niemiło jej to było”23. Trudno osądzać, ile w tym stwierdzeniu obiektywizmu, ale późniejsza reakcja rodziców na decyzję córki o wstąpieniu do klasztoru zdaje się niejako potwierdzać to spostrzeżenie. Po początkowym kategorycznym sprzeciwie, kiedy usilne namowy, obietnice i groźby wobec córki nie doprowadziły do zmiany jej postanowienia, rodzice wyrazili zgodę. Jednakże z opisu Marchockiej widać, że ojciec tę akceptację jej wyboru przypłacił własną chorobą ${ }^{24}$. Ze słów ojca opierającego się woli córki przebija nie tylko autentyczna troska o nią i o jej przyszłość, ale przede wszystkim szczere uczucie, tak często skrywane przez ówczesnych mężczyzn pod pozorami oschłości. Autorka wspominała także ostatnią chorobę swojego ojca i własne zabiegi wokół dobrego przygotowania go do śmierci:

czyniłam, com mogła, upominając go pisaniem, żeby się sposabiał do dobrej śmierci, przypominając jego pragnienia i prośby, bo najwięcej o to prosił, żeby mu uprosić śmierć dobrą u Pana. Wiodłam go najwięcej do sakramentów, do spowiedzi, do skruchy przy dobrych jeszcze zmysłach; był tak dobry, że przyjmował wszystko dobrze i powolnie czyni²5.

22 B. Popiołek zauważyła, że w listach kobiet doby saskiej: „Zastanawia fakt, że mimo utrzymywania się silnie patriarchalnych stosunków w rodzinie staropolskiej dzieci, a przede wszystkim córki, znacznie częściej używały w korespondencji formy zdrobniałej czy wręcz pieszczotliwej zwracając się do ojców, niż do matek”. B. Popiołek, Kobiecy świat, s. 239. Podobnie bliskie relacje ojca i córki możemy zaobserwować w relacji innej autorki, Anny ze Stanisławskich Zbąskiej, która dała temu wyraz niejednokrotnie w swojej wierszowanej autobiografii. Zob. A. Stanisławska, Transakcyja albo opisanie całego życia jednej sieroty przez żałosne treny od tejże samej pisane roku 1685, wyd. I. Kotowa, Kraków 1935.

23 Teresa od Jezusa (Marianna Marchocka), Autobiografia mistyczna, s. 45.

24 „Ociec był tak strapiony, że do politowania nie wiem komu by nie był, patrząc nań; aż się na gorączkę rozniemógł. Powiadał mi, że nie mógł czuć, wystawiając sobie wszystkie ciężkości (nic cięższego w naturze swojej nad to) i kiedy by mnie umarłą na marach widział, nie miałby takiego żalu i ciężkości, bo by już widział koniec mój, ale jako on mówieł: «Dawać mię jako na ustawiczne umieranie, wiedzieć, żem jest, a nie mieć mię, cięższa mu to była [rzecz]». Jako się na Boga oświadczal, mówiąc do Niego: «Nie mogę nic większego uczynić dla Ciebie, Panie, jako czynię, a wielką rzec[z] czynię». Teresa od Jezusa (Marianna Marchocka), Autobiografia mistyczna, s. 73. 
Te zabiegi, już wówczas matki Teresy od Jezusa, ukazują oprócz troski ukierunkowanej na zbawienie duszy ojca, prawdziwe przywiązanie do niego, kiedy walczyły w niej chęć przyjścia mu z duchowym wsparciem, z zasadami zakonnej reguły polecającej, by nie wchodzić w sprawy tego, „co do krwie i świeckich [należy]”26.

Matka z opisu Autobiografi to kobieta pobożna, gospodarna i zapobiegliwa, dbająca o dom i swoje dzieci. Marianna, opisując początki swojego życia, które zapewne znała z opowieści matki, docenia jej troskę o siebie:

nosząc mnie w żywocie matka moja s[t] lukła się z wozu wywróceniem barzo i mnie w sobie zabiła, że już nie miała nadziejej, żebym miała być żywa. Udała się w tym swym żalu do Naśw[iętszej] Panny, jachała do Częstochowy i tam mnie przed obrazem Jej oddała, prosząc Panny Naśw[iętszej] o żywot mój, żebym nie została wiecznie bez zażywania Boga (bo o to największy żal miała ${ }^{27}$.

Ta troska o religijne wychowanie córek była cechą charakterystyczną Elżbiety Marchockiej. Marianna opisała, jak wyglądało kształtowanie jej własnej pobożności pod okiem matki:

Matka moja dawała nam dobre wychowanie, o od młodości lat wiodła nas do Pana Boga, do służenia Mu i rada w nas widziała, kiedychmy się do Pana Boga miały. Osobliwie zalicała nam nabożeństwo do Naświętszy Panny; a na każde święto jej zawsze się spowiadała i komunikowała z nami. Nie pamiętam, żebym które święto Naświętszy Panny bez komuniej kiedy opuściła. Różaniec Naświetszy Panny, zaraz jakom pacierz umiała, nam naznaczała mówić. [...] Miała też szczególne nabożeństwo do św. Katarzyny panny i męczenniczki, i nas go uczyła. Kazała odprawiać na każdy rok przed jej świętem na siedem niedziel pacierzy piętnaście z inszymi modlitwami, pościła do niej post i z nami; co tydzień, to inszy dzień bralichmy. Mszy św. słuchać w te dni trzeba było, z inszymi różnymi do niej nabożeństwy [...]. Sporządzali mi też wszystek czas przez cały dzień, w każdą godzinę czym się bawić, do modlenia, do nauk, do czytania, do robót, a na każdy dzień powinność ta moja byłą czytać żywoty świętych, tego zwłaszcza świętego, którego dzień przypadał i powiedzieć go przed matką zawsze ${ }^{28}$.

Zabiegi matki miały w córkach wyrobić nawyk nie tylko do modlitwy i nabożeństwa, ale także pracowitość i dobre wykorzystanie każdej chwili dnia, bliskie średniowiecznej benedyktyńskiej zasadzie: „ora et labora”.

26 Tamże.

27 Tamże, s. 38-39.

28 Tamże, s. 42-43. 
W opisie następnych lat swojego życia Marianna sprawiedliwie jednak zauważała, że matka w dziecięcych konfliktach między nią a starszą siostrą zawsze stawała po jej stronie, biorąc w obronę, chociaż według autorki nie wynikało to z „afektu” do niej, a jedynie z jakiegoś przeczucia matki, że Marianna jeszcze dość w swoim życiu się nacierpi ${ }^{29}$. Potrafiła jednak okazać w stosunku do niej także „twardą rękę”, zwłaszcza gdy w młodzieńczym wieku Marianna swoim zachowaniem budziła jej zaniepokojenie, jak zdarzyło się to chociażby podczas pobytu Marchockich na zamku Lubomirskich w Nowym Wiśniczu. Kiedy spędzającym tam czas na tańcach i zabawie młodym skończyły się pomysły, „a nie mając już co wymyślać, namówiłam się z niektórymi towarzyszkami, żechmy się ubrały po mnisku, jako chodzą bernardynki, zmyślając dla rekreacyi, iż te zakonnice skądś przyjachały". Wszyscy podziwiali ten koncept i wygląd dziewcząt (szczególnie Marianny), ale „matka moja obaczywszy mię tak, dała mi dobrze w gębę i gniewem zapalona rzekła do onej pani (Zofia Lubomirska): «Coś mi tak dziwnego z mojej córki uczyniła?»”30. Gniew matki wynikał może z podświadomego lęku przed wyborem zakonnego życia także przez młodszą córkę, gdyż wcześniej taką decyzję podjęła już starsza Elżbieta, która wstąpiła do klasztoru klarysek w Starym Sączu ${ }^{31}$.

Tę relację o własnej rodzinie uzupełnia opis rodzeństwa, a właściwie jedynie siostry, gdyż o braciach (a wiemy, że posiadała przynajmniej jednego, Mikołaja) nie ma w Autobiografii żadnej wzmianki. Nieliczne wersy, które autorka jej poświęciła, są raczej lakoniczne, ukazując typowy układ wspólnie wychowujących się dziewcząt, których dzieli na tyle duża różnica wieku, że wpływa ona znacząco na jakość siostrzanej zażyłości. Widać w tej relacji chęć naśladowania Elżbiety przez Mariannę, a także wszystkie utrapienia, które zwykle ma starsze rodzeństwo z młodszym. W jej wspomnieniach można jednak zobaczyć także opiekuńczość starszej siostry wobec nastoletniej już Marianny, która oznajmieniem swojej decyzji o wstąpieniu do klasztoru naraziła się na tak mocne niezadowolenie rodziców, że przybierało ono nawet tak gwałtowny wyraz:

29 Tamże, s. 45-46: „Jednak ona nade mną większe politowanie zawsze pokazowała i nigdy mnie nie mogła karać, chociaż była [m] tak zła, i tę starszą siostrę gromieła zawsze, kiedy mi co uczyniła, mówiąc: «Daj pokój Kaimie, temu niewinnemu Ablowi». Powiadała matka, że coś we mnie widziała, że nie mogła na mnie bez politowania wejrzeć, i tak to sobie wykładała i mówieła, «że ta na jakieś cierpienie albo na sieroctwo przydzie», a kiedy mi kto co uczynił albo na mię skarżył, nie mógł jej więcej obrazić i mowieła: «Jakobyście mię po sercu darli, będzie mieć za swe»”.

30 Tamże, s. 51.

31 S. Kunegunda (Elżbieta) Marchocka (ok. 1600-1670), w 1615 r. wstąpiła do klasztoru klarysek w Starym Sączu. 
Raz ociec mój, upiwszy się, a w swoim gniewie przeciw mnie będąc, przyszedł mnie pytać, jeśli jeszcze w swoim uporze (jako on zwał) trwam do klasztoru? Odpowiedziałam, że trwam i nigdy nie odmienię przedsięwzięcia mego Bogu w zakonie służyć. Wyrwał szable - czy mnie zabić, czy ranić chcial, nie wiem, bo w gniewie był wielkim - już się zamierzył strasznie na mnie, uchwyciła go starsza siostra z oną szablą za rękę, krzyknąwszy, bo jeno sama przy mnie była - wzięli ją byli natenczas z klasztoru - a mnie kazali zejść mu z oczu³

To także dzięki swojej siostrze poznała życie w klasztorze, mieszkając kilka miesięcy u klarysek w Starym Sączu, gdzie w trosce o jej bezpieczeństwo podczas niespokojnego czasu w Rzeczypospolitej wysłali ją rodzice. I choć nie czuła, że chciałaby tam pozostać na zawsze, to jednak ten pobyt utwierdził ją w przekonaniu o wyborze życia zakonnego dla siebie.

\section{Klasztor - akceptowalny margines obowiązującego wzorca}

Wybór klasztoru na miejsce realizacji swojego życia, pomimo że w pewnym stopniu mieścił się w ogólnie przyjętym i akceptowalnym wzorcu „świata kobiecego” doby staropolskiej, to jednak nigdy nie był opcją podstawową czy dostępną dla wszystkich. Już samo wstąpienie do zakonu musiało być dobrowolnym wyborem kandydatki, gdyż na to (szczególnie od soboru trydenckiego) Kościół kładł duży nacisk. Chroniło to także klasztory przed dość kłopotliwymi w życiu codziennym zakonnicami, które nie wybrały tego miejsca dla siebie, a zostało im ono narzucone przez rodzinę ${ }^{33}$. Był to zatem jeden z niewielu wyborów dotyczących własnej przyszłości, który kobieta tamtej epoki mogła podjąć samodzielnie, a często nawet wbrew opinii otoczenia ${ }^{34}$. Widać to dobrze na przykładzie Marchockiej, która opisuje opór i zmagania rodziców z jej decyzją. Ta postawa rodziców Marianny była jednak w ówczesnych czasach reakcją rzadziej spotykaną, gdyż przeważnie wybór klasztoru przez córkę traktowano jako wyróżnienie dla rodziny. Dostrzegała to sama Marchocka, zapisując: „Niezwyczajny to był sposób rodziców takie żale i opłakiwanie córek do zakonu, jakie oni czynili z podziwieniem prawie wszystkich ludzi, a osobliwie mat-

32 Teresa od Jezusa (Marianna Marchocka), Autobiografia mistyczna, s. 58.

33 Por. M. Borkowska, Życie codzienne, s. 15.

34 Analizę najczęstszych motywacji kandydatek do zakonu i rodzicielskich reakcji na ten wybór przeprowadziła M. Borkowska (Życie codzienne, s. 11-18). 
ka jako białagłowa; nie wiem, jako jej już łez stawało"35. Zwykle w takich okolicznościach rodzina nie desperowała, a raczej okazywała radość, same dziewczęta zaś podejmowały taką decyzję, kierując się zapewne głosem powołania, ale być może i pragnieniem większej osobistej niezależności, którą klasztor - wbrew pozorom zapewniał kobiecie w staropolskim społeczeństwie ${ }^{36}$. Uniezależnienie się od wpływów rodziny i wyłamanie się z ogólnie akceptowanej roli żony i matki zastępowano nową rodziną i odmiennymi zasadami funkcjonowania, budowanymi w znacznej mierze na prawach opartych na regule zakonnej, która zakładała pewną równość wszystkich zakonnic, niezależnie od pochodzenia. Nie było oczywiście mowy o demokracji, gdyż hierarchia była zachowana także za furtą klasztorną, ale był to wolny wybór kobiety, która podejmując decyzję o byciu zakonnicą, dobrowolnie godziła się na te zasady. Warte to chyba podkreślenia w odniesieniu do społeczeństwa, w którym wśród kobiet na pewno tylko wdowa miała więcej swobody w dysponowaniu własną osobą, o ile nie została zmuszona przez otoczenie do ponownego ożenku.

Klasztor wówczas był także niemal jedyną możliwością zdobycia przez kobietę wykształcenia, tym bardziej że taką edukacyjną działalność prowadziła większość żeńskich zakonów doby potrydenckiej. Oprócz wychowania w duchu katolickiej reformy dziewczęta mogły zdobyć umiejętność czytania, pisania, śpiewu, haftowania i rachowania, a także podstawy języków obcych, przede wszystkim łaciny, ale i coraz modniejszego języka francuskiego ${ }^{37}$. Jest rzeczą oczywistą, że prowadzące owe szkoły zakonnice musiały także nabyć odpowiedni poziom wykształcenia, pozwalający im przekazywać wiedzę innym. Posiadanie pewnej intelektualnej „sprawności”

\footnotetext{
35 Teresa od Jezusa (Marianna Marchocka), Autobiografia mistyczna, s. 57.
}

36 E.E. Wróbel, Kobieta w Kościele sarmatów, [w:] Charisteria Tito Górski oblata. Studia i rozprawy ofiarowane profesorowi Tytusowi Górskiemu, Kraków 2003, s. 309-324.

37 K. Górski, Matka Mortęska, Kraków 1971, s. 72-73; R. Pelczar, Klasztorne szkoty żeńskie $w$ Polsce $w$ XVI-XVIII w. Problematyka i perspektywy badawcze, Nasza Przeszłość 89 (1998), s. 104-105; H. Barycz, Kartka z dziejów staropolskiego wychowania dziewcząt, Nasza Przeszłość 4 (1948), s. 157-178; A. Rybak, H. Otorowska-Wrońska, Szkoła PP. Norbertanek w Krakowie, Warszawa 1998; R. Gąsior, T. Matuła, Szkoła Sióstr Prezentek w Krakowie w latach 1627-1918, Lublin 1998; E. Sander, Działalność edukacyjna i wychowawcza krakowskich klarysek, Kraków 2010; A. Szylar, Działalność oświatowa benedyktynek sandomierskich w latach 1616-1685, Lublin 2002; taż, Ideaty wychowawcze w klasztornych szkotach żeńskich w okresie potrydenckim do początków XIX wieku, Paedagogia Christiana 2 (2012), s. 11-27; taż, Działalność wychowawczo-edukacyjna żenskich zgromadzeń zakonnych w Małopolsce $w$ okresie potrydenckim do 1815, Kraków 2012; taż, Wzorce wychowania do życia $w$ rodzinie przekazywane dziewczętom $w$ szkołach klasztornych (XVII-XIX w.), Biuletyn Historii Wychowania 30 (2013), s. 25-41. 
było nieodzownym czynnikiem umożliwiającym prawidłową formację zakonną, szczególnie w ujęciu reformy z XVI w. W tym nurcie m.in. reformatorka polskich benedyktynek Magdalena Mortęska wprowadziła do ich klasztorów obowiązkową naukę czytania po polsku i po łacinie oraz zobowiązała siostry (zwłaszcza te na początku drogi zakonnej) do własnoręcznego spisywania swoich medytacji (czyli musiały także posiadać umiejętność pisania). Uczyniła z tego nawet jeden z kryteriów dopuszczających siostry do złożenia profesji zakonnej ${ }^{38}$. To właśnie środowisko zakonne wydało liczne pisarki, które na potrzeby klasztoru prowadziły kroniki zakonne, tworzyły pisma dotyczące spraw duchowych, pieśni czy poezje, a także żywoty współsióstr bądź mistyczne autobiografie, czego przykładem jest dzieło autorstwa Matki Teresy Marchockiej ${ }^{39}$. Chyba nie będzie błędem stwierdzenie, że było to najlepiej wykształcone grono kobiece dawnej Rzeczypospolitej, z którym konkurować mógł jedynie dwór królewski i to raczej w późniejszym okresie, kiedy to wraz z francuskimi królowymi przyszła także do nas moda na bycie białogłową wykształconą, czyli „sawantką”40. Klasztor zaś dawał taką możliwość właściwie przez całe średniowiecze, stanowiąc ciekawy przykład kobiecej emancypacji (oczywiście na miarę swoich czasów) w typowo męskim świecie.

Czasami klasztor stawał się także swoistym azylem dla kobiet, które z różnych względów musiały szukać takiego miejsca odosobnienia. Trudne sytuacje, czasem brak opieki na starość, niejednokrotnie zmuszały je do korzystania z pomocy zakon$\mathrm{nic}^{41}$. Literatura przechowała m.in. wspomnienie schronienia udzielonego w $1612 \mathrm{r}$. przez krakowskie bernardynki Zofii Dembińskiej, formalnie poślubionej już Aleksandrowi Koniecpolskiemu, która pragnąc unieważnić małżeństwo, uciekła do klasztoru wraz ze swoją siostrą Dorotą. Cała sprawa zakończyła się porwaniem obu sióstr przez Koniecpolskiego, w czasie którego mocno ucierpiał klasztor i same mniszki ${ }^{42}$. Prawie pół wieku później także autorka innej autobiografii, Anna ze Stanisławskich

38 K. Górski, M. Magdalena Mortęska i jej rola $w$ reformie trydenckiej $w$ Polsce, Nasza Przeszłość 34 (1971), s. 136; K. Kaczor-Scheitler, Działalność pisarska zakonów żeńskich w dobie baroku, Acta Universitatis Lodziensis. Folia Literaria Polonica 13 (2010), s. 78.

39 M. Borkowska, Życie codzienne, s. 295-296; taż, Panny siostry w świecie sarmackim, Warszawa 2002, s. 81, 307-309. K. Targosz, Piórem zakonnicy, s. 10-14; K. Kaczor-Scheitler, Dziatalność pisarska, s. 77-89.

40 K. Targosz, Sawantki $w$ Polsce $w$ XVII $w$.

${ }^{41}$ K. Targosz, Piórem zakonnicy, s. 162-168; M. Borkowska, Życie codzienne, s. 58-60.

42 T. Graff, B. Wołyniec, E.E. Wróbel, Mikołaj Zebrzydowski (1553-1620). Szkic biograficzny, Kraków 2020, s. 154. 
Zbąska (ok. 1651-1701), korzystała z takiego schronienia u warszawskich wizytek, oczekując na unieważnienie swojego pierwszego małżeństwa z Janem Kazimierzem Warszyckim. Ta gościna trwała kilka miesięcy i z czasem mocno ciążyła mniszkom, gdyż całej sprawie towarzyszyły okoliczności, które poważnie mogły zaszkodzić samemu klasztorowi ${ }^{43}$. Często z pobytu w klasztorze korzystały także wdowy, zwłaszcza fundatorki czy dobrodziejki danego zakonu, dopuszczane przez mniszki do współudziału w swoim życiu w poczuciu wdzięczności za otrzymane dobro ${ }^{44}$.

Jednak dla rodziców Marianny jej wybór był trudny do przyjęcia pomimo tych wszystkich atutów, które kobiecie oferował klasztor. Może związane to było także z zakonem, który wybrała córka, o czym mogłoby świadczyć stwierdzenie ojca przytoczone przez Marchocką:

Zadziwił się ociec, to usłyszawszy ode mnie, i powiedział, że jego intencyja i wola była do Sąc [z]a do klasztoru mię dać, ale kiedy ja tam [tzn. do karmelitanek do Krakowa] chcę, kędy niepodobna, on też już wolen od obietnicy i nikędy nie da, a do takiego zakonu twardego, dziwnego, co to i grzeszą nieludzkim żywotem żyjąc, ale zabijają się, ani myślić; raczej żebym umarła, niż mi tam wstąpić dozwolit ${ }^{45}$.

Być może od samej decyzji wstąpienia do klasztoru to właśnie rodzaj zakonu był dla rodziców trudniejszy do przyjęcia. Przybyłe w 1612 r. do Polski karmelitanki bose były postrzegane jako mające szczególnie „ostrą” regułę, która była niełatwa do zaakceptowania przez ludzi przyzwyczajonych do tradycyjnie funkcjonujących klasztorów żeńskich. Te nowe i dziwne mniszki nie jadały mięsa, cały dzień milczały i unikały ludzi, a kiedy musiały mieć z nimi kontakt, to zasłaniały twarz welonem. Legendarne prawie stały się też podejmowane przez nie umartwienia, które z pewnością trwogą napawały niejedno rodzicielskie serce ${ }^{46}$. Nie dziwota, że ojciec Marianny nie chciał jej dać na to „ustawiczne umieranie” już za życia.

\footnotetext{
43 Zob. A. Stanisławska, Transakcyja albo opisanie całego życia, s. 67.

44 Przykładem może być Anna Lubomirska, fundatorka i dobrodziejka klasztoru dominikanek na Gródku w Krakowie, która niejednokrotnie korzystała z tej możliwości. Por. E.E. Wróbel, Kobieta $w$ Kościele sarmatów, s. 317-318.

45 Teresa od Jezusa (Marianna Marchocka), Autobiografia mistyczna, s. 66.

46 Por. E.E. Wróbel, Widzialny znak Niewidzialnego, [w:] Europejczyk wobec sacrum. Wczoraj i dziś, red. J.C. Kałużny, Kraków 2005, s. 47-56. Trudno w pełni poznać i jednoznacznie zrozumieć obawy rodziców Marianny Marchockiej i ich „łatwiejszą” zgodę na wybór klasztoru w Starym Sączu. Być może była to dla nich przestrzeń już bardziej „oswojona” dzięki pobytowi w nim starszej córki.
} 
Widać zatem, że klasztor był miejscem ważnym nie tylko pod względem wyznaniowym, lecz także społecznym, stanowiąc szczególny obszar kobiecej promocji. Dla samych mniszek był swoistą formą emancypacji w typowo męskim świecie, nie dając może sposobności do całkowitej niezależności, ale oferując poczucie większej możliwości samostanowienia o swoim życiu oraz rozwoju własnych talentów ${ }^{47}$. Klasztor pełnił ważną rolę także w stosunku do kobiet z zewnątrz, zwłaszcza pochodzących ze stanu szlacheckiego i mieszczaństwa, zapewniając bezpieczne schronienie i okazję do pielęgnowania własnego rozwoju duchowego. Jednakże z oczywistych względów tematyka dotycząca roli klasztoru w staropolskim kobiecym świecie jest nieodłącznie związana przede wszystkim z zagadnieniem kobiecej religijności tego okresu, w której wśród wielu aspektów ważne miejsce zajmował właśnie klasztor.

Religia była niewątpliwie jednym z ważniejszych czynników, który kształtował życie i mentalność kobiet w dobie staropolskiej ${ }^{48}$. Wydaje się nawet, że była to jedna $\mathrm{z}$ tych nielicznych sfer życia społecznego, gdzie kobieta była traktowana na równi z mężczyzną, a nawet w niektórych obszarach życia religijnego odgrywała ważniejszą od niego rolę. Znamienne, że wśród najwybitniejszych postaci polskiej duchowości XVI czy XVII w. zdecydowany prym wiodą kobiety ${ }^{49}$. Wystarczy przywołać tutaj przykład wspominanej już matki Magdaleny Mortęskiej, która doprowadziła do reformy klasztorów benedyktyńskich w duchu reformy trydenckiej i jest często porównywana ze św. Teresą z Avila ${ }^{50}$, czy inne świątobliwe benedyktynki i karmelitanki żyjące w tamtym czasie. Jakże musiały być to nietuzinkowe osobowości, które spoza klasztornej kraty potrafily promieniować na innych prawdziwą świętością. Wydaje się zatem, że klasztory odgrywały niezwykle ważną rolę nie tylko w edukacji i religijnym wychowaniu niewiast, lecz także w rozwoju ich życia duchowego. Dotyczyło to zwłaszcza tych, które w tej ostatniej kwestii poszukiwały czegoś więcej, niż mogły otrzymać w duszpasterstwie parafialnym.

Ze zrozumiałych względów ta problematyka zajmuje dużo miejsca w autobiografii karmelitanki Marchockiej. Autorka próbowała przecież przelać na papier kształt własnej drogi duchowej. Przy tej okazji przekazała również bardzo plastyczny obraz religijności własnej matki, pozwalający przypuszczać, jak mogło wyglądać wychowanie religijne dzieci, zwłaszcza córek, w przeciętnym szlacheckim dworku tego

\footnotetext{
47 Por. M. Borkowska, Życie codzienne; K. Targosz, Piórem zakonnicy.

48 Por. B. Popiołek, Kobiecy świat, s. 29-150.

49 Por. K. Górski, Zarys dziejów duchowości, s. 91-92.

50 Tenże, M. Magdalena Mortęska, s. 131-176; tenże, Matka Mortęska.
} 
okresu, o czym wspomniano już wyżej. Można zauważyć, że była to tradycyjna pobożność, w której ważne miejsce zajmował kult świętych, ustne modlitwy i proste praktyki religijne. Trudno jednak ją lekceważyć i odmawiać jej duchowej głębi, gdyż wzrastająca w tej atmosferze Marianna potrafiła wypracować na bazie tych praktyk własny sposób zwracania się do Boga, w którym z czasem zaczęła dominować medytacja i modlitwa myślna oraz różne umartwienia ${ }^{51}$. Należy przypuszczać, że życie religijne większości ówczesnych kobiet, zwłaszcza z warstwy szlacheckiej, nie było powierzchowne - oparte jedynie na zewnętrznej stronie kultu - lecz bardzo często łączyło się z autentycznym życiem wewnętrznym. I nie dotyczyło to jedynie zakonnic, ale także żon i matek, czego przykładem była chociażby wspominana wyżej Elżbieta Marchocka, matka Marianny.

\section{Otoczenie - wzbogacenie funkcjonującego modelu}

Świat kobiecy, chociaż mocno ograniczony w tamtym czasie do ścian domu rodzinnego, nie zamykał się jednak na inne osoby z otoczenia: dalszą rodzinę, przyjaciól, sąsiadów. Także w Autobiografii relacje łączące autorkę z rodzicami i z siostrą nie są jedynymi opisywanymi przez nią więziami. Ze zrozumiałych przyczyn głównym przedmiotem zainteresowania tego dzieła nie były jednak relacje z innymi ludźmi, chociaż ich opis zajmuje w nim także niepoślednie miejsce, lecz osobisty kontakt pisarki z Bogiem. To zdecydowanie była w jej życiu najważniejsza relacja. Znamienne, że Marianna nie przedstawiła wprost swoich motywów, dla których chciała zostać zakonnicą, opisując jedynie zabiegi wokół realizacji tego zamiaru. Jednakże z pozostawionych wspomnień można wywnioskować pośrednio, że zasadniczym powodem tej decyzji była chęć całkowitego oddania się Bogu. Było to dla niej pragnienie wcześniejsze niż sama decyzja o zostaniu zakonnicą. Świadczyć o tym może chociażby jej prośba o możliwość życia w czystości, skierowana do Boga jeszcze w dzieciństwie, choć sama Marchocka zdawała sobie sprawę z własnej niedojrzałości, pisząc: „bom sama nie wiedziała, czegom prosieła, a to zawsze o tom prosiła” ${ }^{52}$. Można zatem stwierdzić, że chociaż Marianna nie określiła wprost swej relacji z Bogiem, podstawą jej decyzji nie był jedynie zachwyt nad samym życiem zakonnym (często ujawniała swe krytyczne zdanie na ten temat), lecz odczuwana przez nią osobista więź z Chrystusem - zażyłość, którą bez wahania można określić mianem miłości.

51 Teresa od Jezusa (Marianna Marchocka), Autobiografia mistyczna, s. 45, 47, 56, 77, 201.

52 Tamże, s. 43. 
Była to miłość przeżywana na inny sposób i w odmiennych realiach niż w wypadku tradycyjnych biografii kobiecych, ale przecież efekt był bardzo podobny. To uczucie dawało jej poczucie spełnienia, określało sens życia, które przecież nie było wolne od zmartwień i trudności, zwłaszcza wtedy, gdy Marchocka przeżywała męki, czując się opuszczoną przez Boga, poddawaną oschłościom i pokusom.

Jednakże poczynione przez autorkę zapiski ujawniają jeszcze jedną sferę zainteresowania ówczesnych kobiet, zwłaszcza szlachcianek, także (chociaż może to wydawać się nieco dziwne) zakonnic. Była nią polityka, a raczej sprawy ojczyzny, w które bezpośrednio byli zaangażowani ich ojcowie, mężowie i bracia. Nie mogąc uczestniczyć osobiście w sejmach czy wojnach, żywo interesowały się wszystkim, co dotyczyło nie tylko najbliższego sąsiedztwa, lecz także całego kraju. Nawet do dzieła klauzurowej zakonnicy przedostały się wiadomości dotyczące „wielkich tego świata” - a konkretnie pary królewskiej Jana Kazimierza i jego żony, Ludwiki Marii. Królowa osobiście odwiedzała warszawskie karmelitanki, niekiedy zatrzymując się na dłużej w klasztorze, polecając modlitwie sióstr intencję narodzenia długo oczekiwanego królewskiego potomstwa. Odpowiadając na prośby królowej, zakonnice oprócz modlitw podejmowały także różne umartwienia, a kiedy urodziła się córka - Maria Anna Teresa - już w kołysce została przeznaczona do Karmelu ${ }^{53}$. Niestety, o czym już nie napisała Marchocka, urodzona w 1650 r. królewna żyła jedynie rok. Po śmierci ubrano ją w karmelitański habit i pochowano w kościele tychże sióstr na Krakowskim Przedmieściu ${ }^{54}$. Marchocka zapisała jeszcze jeden, nieco tajemniczy epizod dotyczący jej osobistych kontaktów z najważniejszymi osobami w państwie. W 1649 r., w oktawie uroczystości Wniebowzięcia Matki Bożej, miała widzenie, w czasie którego - jak sama zapisała - poczuła „wielkie przynaglenie, by prosić za króla je[go]m[o]ści i oddawać go Naśw[iętszej] Pannie, żeby mu uprosiła zwycięstwo" "55. Jan Kazimierz znajdował się bowiem wówczas w obozie pod Zborowem, szykując się do bitwy. Według pisarki także król wraz z kanclerzem Ossolińskim widzieli Marchocką w obozie „upewniającą, że im nic nie będzie" ${ }^{6}$. Widać zatem, że nawet zakonna klauzura i zamknięcie nie stanowiły przeszkody, kiedy trzeba było wspomóc króla i Ojczyznę.

Wbrew oczekiwaniom niewiele miejsca matka Teresa od Jezusa poświęca relacjom z innymi siostrami z klasztoru. Co prawda, pojawiają się konkretne imiona

\footnotetext{
53 Całą tę historię Marchocka opisuje dosyć szeroko, zob. tamże, s. 270-271.

54 B. Fabiani, Na dworze Wazów w Warszawie, Warszawa 1988, s. 146-148.

55 Teresa od Jezusa (Marianna Marchocka), Autobiografia mistyczna, s. 273.

56 Tamże, s. 274.
} 
sióstr, zwłaszcza przełożonych, ale mało jest przykładów codziennych wzajemnych odniesień i kontaktów. Prawdopodobnie wynikało to z tego, że spowiednik Marchockiej, na którego polecenie spisywała autobiografię, doskonale znał te realia, więc nie było potrzebne dodatkowe wyjaśnianie pewnych kwestii. Jednakże podczas snutej przez nią opowieści niejako w tle poznajemy również trudności, które autorka przeżywała w kontaktach z siostrami, szczególnie gdy przełożona nie pojmowała jej duchowej drogi, próbując m.in. narzucić jej inny sposób modlitwy ${ }^{57}$, czy kiedy siostry nie rozumiały istoty jej cierpień duchowych ujawniających się na zewnątrz w postaci objawów przypominających różne choroby ${ }^{58}$. Trudno jej było także wtedy, gdy była przełożoną i pomimo własnych słabości musiała jeszcze pamiętać o siostrach, okazując im swoją troskę i zainteresowanie ${ }^{59}$.

Osobną grupę ludzi, którzy stosunkowo często pojawiają się na kartach autobiografii, poszerzając krąg osób z najbliższego otoczenia, stanowili ojcowie karmelici i lekarze. Ci pierwsi byli bardzo ważni w życiu matki Teresy od Jezusa, bo jak sama zapisała: „Miałam to zawsze w zwyczaju, kiedym z którym ojcem konferencyją czynić miała albo się w czym radzić, żem prosiła Pana, żeby podał, co wola Jego i oświ[e]cił przez nich, postanawiając jako od Niego samego przyjąć, jako mi powiedzą" ${ }^{60}$. Byli oni dla niej przede wszystkim przewodnikami w życiu duchowym, dlatego też z ufnością zawierzała ich osądowi swoje przeżycia wewnętrzne, często niezrozumiałe dla niej samej. Nie każdy z nich też potrafił wykazać odpowiednie podejście do doświadczanych przez nią trudności, często narażając ją na dodatkowe cierpienia $^{61}$. Na szczególne wspomnienie zasłużył o. Ignacy od św. Jana Ewangelisty, który będąc przez prawie dwadzieścia lat jej spowiednikiem, polecił jej opisać swoją drogę duchową, co zaowocowało powstaniem autobiografii ${ }^{2}$.

\footnotetext{
57 Tamże, s. 198-199.
}

58 Opisała zabiegi sióstr w czasie jej choroby, kiedy podejrzewano, że ma „kaduk”, a jej zaprzeczenia były przyjmowane z nieufnością: „a jeszcze rozumiały (siostry), że się ja to ratować nie chcę i łajały mi, gniewały się na mnie. O, mój Panie, bądź błogosławiony za wszystko!”, tamże, s. 211.

59 Jak sama zapisała: „Miałam wiele ucisków i utrapienia i Pan mię sam opuszczeniem często ciężkim prowadzieł, i z utrapienia sióstr musiałam mieć co czuć. Kiedym bym była tylko sama, nic by mi to, ale z siostrami, Pan sam zna, jaki krzyż był”, tamże, s. 222.

60 Tamże, s. 166.

61 Na temat przewodników duchowych matki Teresy od Jezusa zob. J.W. Gogola, Życie mistyczne Teresy, s. 77-87.

62 Teresa od Jezusa (Marianna Marchocka), Autobiografia mistyczna, s. 85-87. 
Do drugiej grupy ludzi przychodzących z zewnątrz do klasztornego „świata” należeli lekarze, którzy ze względu na nieustanne zapadanie na zdrowiu Marchockiej j3 zasłużyli na dość częstą obecność nie tylko w jej życiu, lecz także w zapiskach. Wydaje się, że autorka nie miała o nich (czy raczej o ich umiejętnościach) zbyt dobrego zdania, chociaż to wrażenie może wynikać $\mathrm{z}$ tego, że ich pojawianie się na kartach Autobiografii mistycznej zawsze połączone jest z cierpieniem fizycznym autorki, w którym często zamiast pomocy otrzymywała od nich dodatkowe udręki. Podstawowym sposobem leczenia jej dolegliwości było zawsze puszczanie $\mathrm{krwi}^{64}$ albo powodowanie wymiotów (jeżeli skarżyła się na żołądek) ${ }^{65}$. Najbardziej zajmującą relacją dotyczącą jej chorób jest opis ratowania jej z „kaduka”, jak w czasach staropolskich określano epilepsję ${ }^{66}$. Po serii ataków siostry, bojąc się o jej życie, posłały po lekarza, który:

począł mię zaraz kurować na on kaduk rozmaitymi sposobami, już piciem, mazaniem na te cierpienia, wonianiem, noszeniem przy sobie rzeczy smrodliwych etc. Wiedząc, że mnie na kaduk leczą, z niecierpliwości mojej prosiłam, żebym też sama mogła mówić z doktorem, bo mnie nie przypuszczały. Powiedziałam doktorowi, upewniając, że ja kaduku nie miewam, bo w kaduku nic a nic człowiek nie czuje, czy żywy czy umarły, jakom to widziała i od doktorów znała, a ja bardzo dobrze wiem, co się we mnie w duszy dzieje i ból ciężki serca czuję. Pienienia, ciskania żadnego nie mam, tylko serca samego skakanie, a głowy rzucanie ${ }^{67}$.

Dodatkowo, siostry nie wierząc w jej odczucia, upewniały doktora, że w czasie ataku „ani zmysłów, ani pamięci nie mam”, więc z pewnością to „serdeczny jeno kaduk, ale przecie kaduk" i:

63 Tamże, s. 241 zapisała: „Ja już prawie żadnego dnia nie mam od jakiego bólu albo od jakiej niesposobności wolnego, i jużem zapomniała, a nie wiem, co to zdrowie dobre”.

64 Tamże, s. 187, 245.

65 Tamże, s. 98. Upuszczanie krwi i powodowanie wymiotów to bardzo często w czasach staropolskich stosowany środek leczniczy na różne choroby i dolegliwości, por. E. Nowosielska, Epilepsja w Rzeczypospolitej w XVII-XVIII w., [w:] Wśród córek Eskulapa. Szkice z dziejów medycyny $i$ higieny $w$ Rzeczypospolitej XVI-XVIII wieku, red. A. Karpiński, cz. 2, Warszawa 2015, s. 248; J. Węglorz, Zdrowie, choroba i lecznictwo w społeczeństwie Rzeczypospolitej XVI-XVIII wieku, Toruń 2015.

66 Więcej na ten temat zob. S. Konieczna, Pacjent z padaczka dawniej i dziś, [w:] Dawna medycyna i weterynaria. Pacjent, red. M.Z. Felsmann, J. Szarek, M. Felsmann, Chełmno 2011, s. 51-68; E. Nowosielska, Epilepsja w Rzeczypospolitej, s. 219-257.

67 Teresa od Jezusa (Marianna Marchocka), Autobiografia mistyczna, s. 209-210. 
przyczyniały lekarstw, a mnie męki. Obojgiem się męcząc, ledwo mi już sieł stawało i dziwny Bóg, żem nie umarła z takich dziwów, które ze mną czyniły. Lały wódkami, że i oczy zalewały, pojeły proszkami serdecznymi, a ja i przełknienia mocy mieć nie mogła, że mnie mało nie udusily ${ }^{68}$.

A kiedy i to nie pomagało, siostry prosiły lekarza, żeby coś jeszcze zrobił, on jedynie tłumaczył, że „nie na darmo ta choroba ma ten tytuł wielka, przetoż nie może być łatwo i tak prędko ratowana" ${ }^{\prime \prime}$. Ostatecznie choroby, które przez całe życie towarzyszyły Marchockiej, pod koniec życia unieruchomiły ją całkowicie, a częściowy paraliż sprawił, że nie była już w stanie samodzielnie pisać i końcowe wiersze Autobiografii musiała już dyktować.

\section{Wnioski końcowe}

Historyk zajmujący się historią staropolskiego społeczeństwa ostatecznie zawsze musi postawić sobie pytania dotyczące różnicy pomiędzy kreowaniem pewnego wzorca zachowań a realnym jego funkcjonowaniem. Dodatkowo, pamiętając o uwarunkowaniach tamtej epoki, badacz mający możliwość zapoznania się z „kwestią kobiecą", ocenia ją przede wszystkim z męskiego punktu widzenia, zatem nie może zapominać o czynnikach mających wpływ na kształt tego wizerunku. Równie zajmującą sprawą jest stwierdzenie, w jakim stopniu propagowany przez społeczeństwo staropolskie wzorzec kobiecych zachowań był tworzony i akceptowany przez same białogłowy, a w jakim modelowany i narzucany przez mężczyzn ustanawiających wszelkie zasady i normy ówczesnego funkcjonowania. I może, co ważniejsze, jak dalece popularyzowany kanon wartości i reguł postępowania sprawdzał się w niełatwej przecież staropolskiej codzienności. Czy pomagał kobiecie wypełniać jej życiowe zadania, czy raczej ją krępował? Odnosi się to także do preferowanego wzorca kobiety i matki jako obowiązującego w staropolskim społeczeństwie. Odmienne warianty tego wzorca - jak wdowa czy bezdzietna małżonka - były ogólnie akceptowane, choć uważane za nieco gorsze wersje ideału, gdyż były związane z pewnym brakiem (męża czy dzieci). Dlatego też normalnym dążeniem każdej kobiety, a także jej otoczenia, było odwrócenie tej sytuacji, by mogła ona cieszyć się poczuciem spełnienia.

Lektura Autobiografi mistycznej matki Teresy z punktu widzenia historyka mentalności wydaje się ciekawym zabiegiem, pozwalającym niejako odczytać to źró-

\footnotetext{
68 Tamże, s. 211.

69 Tamże.
} 
dło z innej perspektywy. Analizując wątki poboczne i niejako „drugoplanowe” dla zasadniczej treści, można lepiej zapoznać się ze specyfiką staropolskiego „świata kobiecego".

Jest to tym cenniejsza możliwość, że nieliczne pamiątki pozostawione przez same panie nie zawsze i w dość ograniczonym zakresie ułatwiają wniknięcie w tę rzeczywistość. Wszystkie trudności, jakie narzuca brak źródeł, a także niebezpieczeństwo nadinterpretacji tych nielicznie posiadanych ${ }^{70}$, każą ostrożnie formułować uogólnienia oraz zmuszają do ciągłych poszukiwań świadectw praktycznej weryfikacji konstruowanych przez historyków tez. Dlatego też należy pamiętać, że nawet najlepszy tekst jest nadal jednostkowym potwierdzeniem pewnych zjawisk, które muszą być nadal uzupełniane, by mogły stawać się podstawą formułowanych generalizacji. Dzieło Marchockiej jest dodatkowo świadectwem dość wyjątkowym, gdyż dotyczącym zakonnicy żyjącej niejako na marginesie ogólnie przyjętego wzorca żony i matki, dlatego też trzeba pamiętać, że jej życie nie do końca było typowe dla opisywanej epoki.

Jak zatem w tym kontekście umiejscowić życie zakonne wybierane przez część staropolskich kobiet? Czy był to sposób życia całkowicie odmienny od powszechnie przyjętego wzorca (byłby zatem pewną alternatywą), czy raczej kolejny jego wariant? To niewątpliwie są kwestie do rozważenia w toku dalszych badań, pozwalających na rozstrzygającą i zdecydowaną odpowiedź na owe pytania. Autobiografia mistyczna matki Teresy (Marianny) Marchockiej pozwala jednak sądzić, że pomimo pozornej odmienności życia zakonnicy pozostawała ona nadal w obrębie realizacji tego podstawowego kobiecego modelu doby staropolskiej. I chociaż życie zakonne było społecznie akceptowanym, choć nieco odmiennym sposobem realizacji tego zasadniczego wzorca, to jednocześnie towarzyszyła mu świadomość pewnej elitarności, ponieważ nie był on możliwy do realizowania przez każdą z kobiet. To ograniczenie wynikało przede wszystkim z konieczności posiadania pewnych predyspozycji do tego rodzaju życia, które często określa się mianem „powołania”, i chociaż wówczas nie brakowało chętnych do jego realizacji, przeważnie obawiano się go jako zbyt trudnego. Z czego mogło wynikać to przekonanie? Wydaje się, że podstawową kwestią nie były tu sprawy związane z poziomem życia zakonnic czy ślubami, które składały, ale raczej z poczuciem podwójnego braku towarzyszącego takiej realizacji kobiecości: zarazem braku męża, jak i dzieci. Patrząc na przykład Marchockiej, jak i wielu „panien sióstr” tego okresu, mamy wrażenie, że one same nie odczuwały tego

70 Ważne spostrzeżenia w tym temacie poczyniła B. Popiołek, Kobiecy świat, s. 5-28. 
jako zbyt dużego zubożenia. Klasztor stawał się dla nich światem, który rekompensował w pełni sposób życia pozostawiony poza jego murami. Zawsze jednak trzeba pamiętać, że dostępne źródła w niewielkim jedynie stopniu pozwalają nam poznać świat wewnętrznych kobiecych przeżyć, dlatego też nie można zapominać, że niezależnie od miejsca realizacji własnego życia, wszędzie tam (zarówno w małżeństwie, jak i w zakonie) zdarzały się również przypadki nieszczęśliwych kobiet. Zapewne dlatego, że poczucia spełnienia nie daje sam wzorzec (lub jego wariant), ale sposób jego realizacji, a to już zależy w znacznej mierze od każdej kobiety indywidualnie, co pokazuje także Autobiografia mistyczna matki Teresy Marchockiej.

\section{Summary}

Mystical autobiography by Marianna Marchocka (servant of God, Teresa of Jesus), a Discalced Carmelite (1603-1652) has so far been the subject of interest of researchers mainly from a theological and literary point of view. However, it has not been sufficiently used to study the history of mentality. The article contains ample information about ancient customs and traditions, analysed with respect to the most important personal relations of the then woman-cum-nun: her home, the monastic community and other people in her environment. The main issue was to examine whether religious life for women in the Old Polish era was an alternative to the traditional path of female self-realization (i.e. marriage), or rather one of its variants. Based on this individual example, the latter seems more realistic, placing religious life within a single, adopted model.

Nadesłany: 12 XII 2020

Nadesłany po poprawkach recenzyjnych: 15 I 2021

Zaakceptowany: 21 I 2021

dr Elżbieta Elena Wróbel

Wydział Historii i Dziedzictwa Kulturowego

Uniwersytet Papieski Jana Pawła II w Krakowie

ul. Warszawska 13

31-155 Kraków

elzbieta.wrobel@upjp2.edu.pl 